\title{
Efficacy of the direct-fed microbial Enterococcus faecium alone or in combination with Saccharomyces cerevisiae or Lactococcus lactis during induced subacute ruminal acidosis
}

\author{
J. Chiquette, ${ }^{* 1}$ J. Lagrost,† C. L. Girard, ${ }^{*}$ G. Talbot, ${ }^{*}$ S. Li, † J. C. Plaizier, $\ddagger$ and I. K. Hindrichsen§ \\ *Dairy and Swine Research and Development Centre, 2000 College, Sherbrooke, QC, Canada J1M 1 Z3 \\ †Institut Supérieur d'Agriculture Rhône-Alpes, Agrapole, 23 rue Jean Baldassini, 69364, Lyon CEDEX 07, France \\ ‡Department of Animal Science, University of Manitoba, 12 Dafoe Rd., Winnipeg, Manitoba, Canada R3T 2N2 \\ §Chr. Hansen A/S, 10-12 Bøge Allé, DK-2970 Hørsholm, Denmark
}

\section{ABSTRACT}

This study aimed at investigating Enterococcus faecium alone or E. faecium in combination with Saccharomyces cerevisiae or Lactococcus lactis during a subacute ruminal acidosis (SARA) challenge. Four ruminally fistulated Holstein dairy cows were assigned to the following treatments in a $4 \times 4$ Latin square design: (1) control (CON); (2) E. faecium (EF); (3) EF + S. cerevisiae (EFSC); (4) EF + L. lactis DSM 11037 (EFLL). Each experimental period consisted of $18 \mathrm{~d}$ of adaptation to the respective direct-fed microbial, 3 $\mathrm{d}$ of SARA challenge, and $7 \mathrm{~d}$ of rest. Rumen $\mathrm{pH}$ was recorded every $10 \mathrm{~min}$ over $24 \mathrm{~h}$ on d 17 of adaptation, d 2 of SARA, and d 6 of rest. On the last day of adaptation, SARA, and rest, samples of rumen content (0 and $3 \mathrm{~h}$ after feeding) were taken for volatile fatty acids, lactate, vitamin $\mathrm{B}_{12}$, rumen microbes, and lipopolysaccharides determination. Blood samples (0 and $6 \mathrm{~h}$ after feeding) were taken for the measurement of acute-phase proteins. Dry matter intake and milk yield were recorded daily. During SARA, mean rumen $\mathrm{pH}$ with EFSC (5.94) was not different from that of EFLL (5.95) and tended to be higher than with CON (5.82) or $\mathrm{EF}$ (5.82). Postfeeding vitamin $\mathrm{B}_{12}$ concentrations in the rumen were greater with EFSC $(134.5 \mathrm{ng} / \mathrm{g})$ than with $\mathrm{EF}(99.6 \mathrm{ng} / \mathrm{g}$ ) and tended to be greater when compared with CON (101.2 ng/g) or EFLL (104.9 $\mathrm{ng} / \mathrm{g})$. During rest, prefeed vitamin $\mathrm{B}_{12}$ was greater with EFSC (166.5 ng/g) compared with CON (132.3 $\mathrm{ng} / \mathrm{g})$. The EFSC treatment did better than EF alone on $\mathrm{pH}$ characteristics during adaptation and SARA and on maintenance of ruminal vitamin $\mathrm{B}_{12}$ status during SARA. Milk yield drop from d 1 to 3 of SARA was

Received April 9, 2014.

Accepted September 26, 2014.

${ }^{1}$ Corresponding author: johanne.chiquette@agr.gc.ca smaller with EFSC $(-0.8 \mathrm{~kg} / \mathrm{d}), \operatorname{EF}(-0.9 \mathrm{~kg} / \mathrm{d})$, or EFLL $(-0.9 \mathrm{~kg} / \mathrm{d})$ compared with CON $(-7.5 \mathrm{~kg} / \mathrm{d})$.

Key words: direct-fed microbial, dairy cow, subacute rumen acidosis

\section{INTRODUCTION}

Subacute ruminal acidosis is an important digestive disorder characterized by intermittent rumen $\mathrm{pH}$ depression for prolonged periods due to VFA accumulation and insufficient buffering. These conditions result in an imbalanced microbial flora (e.g., decrease in cellulolytic bacteria and protozoa and proliferation of acid-tolerant bacteria; Petri et al., 2013) and are detrimental to animal health, welfare, and productivity. Khafipour et al. (2009a) suggested that following a grain-based challenge to induce SARA experimentally, LPS or endotoxins translocated into the peripheral circulation. Lipopolysaccharides are components of the cell wall of gram-negative bacteria. They are released when these bacteria lyse or are shed by rapidly growing bacteria. Their translocation into the blood circulation triggers an inflammatory response. These endotoxins are involved in the etiology of multiple metabolic disorders such as acidosis, fatty liver, laminitis, and sudden death syndrome (Ametaj et al., 2005). Indications exist that this inflammatory response during SARA is not limited to the rumen but also affects the lower gut where LPS would be readily absorbed due to increased permeability of the epithelium (Li et al., 2012b).

Direct-fed microbials (DFM) offer a promising avenue to control the imbalanced microflora both in the rumen and in the lower tract. Most rumen bacterial species are $\mathrm{O}_{2}$ sensitive, and both rumen bacteria and protozoa contribute to $\mathrm{O}_{2}$ consumption (Ellis et al., 1989) for the maintenance of an anaerobic environment. Because protozoa number falls with rumen acidity (Slyter, 1976), it can be hypothesized that the $\mathrm{O}_{2}$ scavenging properties of yeasts would favor bacterial growth (Newbold et al., 1996) during a SARA episode. 
Also, Marden and Bayourthe (2005) indicated that the formation of propionate is favored at the expense of lactic acid (stronger acid) when partial pressure of oxygen is low. This would contribute to the elevation of rumen $\mathrm{pH}$ often observed with yeast. In the same line, Nisbet and Martin (1991) reported that yeasts stimulated the growth of lactic acid-utilizing bacteria (LUB). It was hypothesized in the present study that a strain (DSM 11037) of Lactococcus lactis, a lactic acid-producing bacteria showing $\mathrm{O}_{2}$ scavenging efficacy from a preliminary study (Hindrichsen et al., 2012), could replace DFM yeast. Lactococcus lactis DSM 11037 was superior to other bacterial species, among which Enterococcus faecium, in removing $\mathrm{O}_{2}$ (Hindrichsen et al., 2012).

Another hypothesis for improved bacterial growth with yeast is the provision of $\mathrm{B}$ vitamins and other micronutrients such as organic acids to rumen bacteria. Vitamin $B_{12}$ is required by rumen cellulolytic bacteria for optimum growth (Scott and Dehority, 1965). Vitamin $\mathrm{B}_{12}$ is also required by Propionibacterium freudenreichii and Selenomonas ruminantium for the synthesis of propionate (glucose precursor; Dryden et al., 1962). Although vitamin $\mathrm{B}_{12}$ is not produced by yeast, but by bacteria and archaebacteria when cobalt supply is adequate (Martens et al., 2002), yeast supplement improved vitamin $B_{12}$ status in vegans (Donaldson, 2000). As apparent synthesis of vitamin $\mathrm{B}_{12}$ is highly correlated with microbial nitrogen flow (Schwab et al., 2006), if yeast supplement promotes bacterial growth, then it could also favor ruminal synthesis of the vitamin.

Subacute ruminal acidosis is not characterized by accumulation of lactate, unlike acute acidosis. However, when dairy cows are experiencing SARA, ruminal conditions are very unstable and can switch toward the acute form where lactate concentration is no longer controlled by LUB. Khafipour et al. (2009c) reported increased population of Megasphaera elsdenii (LUB) during grain-induced SARA, indicative of increased lactate utilization. It was previously hypothesized that the continuous provision of E. faecium (lactic acid-producing bacteria) in the rumen helps to maintain the activity of the LUB, which will intervene rapidly when a surge of lactate occurs (Nocek et al., 2002).

Previous research demonstrated the ability of the DFM mixture E. faecium + Saccharomyces cerevisiae (EFSC) to stabilize rumen $\mathrm{pH}$ when dairy cows were subjected to a SARA challenge (Chiquette, 2009; Chiquette et al., 2012). The objectives of the present study were to (1) determine additional effects of EFSC at the rumen level and on the inflammatory response of the animal, (2) determine whether S. cerevisiae in the combination EFSC could be replaced by a strain of $L$. lactis showing $\mathrm{O}_{2}$ scavenging efficiency, and (3) compare EFSC to E. faecium alone.

\section{MATERIALS AND METHODS}

\section{Animals, Feeding, Sampling, and Analytical Procedure}

All animals in this experiment were cared for according to the standards set by the Canadian Council on Animal Care in Science (2009). Four ruminally fistulated Holstein dairy cows averaging $616 \pm 38 \mathrm{~kg}$ of BW and $81 \pm 5$ DIM were assigned to the following experimental treatments in a $4 \times 4$ Latin square design: (1) control (limestone carrier without the DFM cultures; CON); (2) E. faecium [mixture of 3 strains: E. faecium $1\left(1.2 \times 10^{9} \mathrm{cfu} / \mathrm{g}\right.$ of commercial product $)$, E. faecium $2\left(1.2 \times 10^{9} \mathrm{cfu} / \mathrm{g}\right)$, and E. faecium $3(1.3 \times$ $\left.\left.10^{7} \mathrm{cfu} / \mathrm{g}\right) ; \mathbf{E F}\right] ;(3) \mathrm{EF}+$ S. cerevisiae $\left(1 \times 10^{9} \mathrm{cfu} / \mathrm{g}\right.$; EFSC); (4) $\mathrm{EF}+$ L. lactis DSM $11037\left(2.8 \times 10^{9}\right.$ cfu/g; EFLL). Direct-fed microbials and limestone carrier were provided by Chr. Hansen (Milwaukee, WI). The dose of DFM given to each animal was calculated according to the average DMI measured during the preceding week. Twice a day (at 0830 and $1530 \mathrm{~h}$ ), DFM were introduced in equal quantities directly into the rumen through the fistula to provide daily a total of 80 mg of commercial product per kilogram of DMI (e.g., $80 \mathrm{mg}$ of commercial product $\times 25 \mathrm{~kg}$ of $\mathrm{DMI}=2 \mathrm{~g}$ of commercial product per day for a given cow).

Each experimental period of the Latin square consisted of $18 \mathrm{~d}$ of adaptation to the respective DFM; 3 $\mathrm{d}$ of SARA challenge; and $7 \mathrm{~d}$ of rest. During adaptation and rest, $97 \%$ of the diet (DM basis) consisted of a conventional early-lactation TMR (Table 1) fed ad libitum twice a day at 0830 and $1530 \mathrm{~h}$. One kilogram of dry hay ( $3 \%$ of the diet on a DM basis), additional to that included in the TMR, was fed once a day at 0730 h. Subacute ruminal acidosis was induced following the method described in Keunen et al. (2002). During SARA, $30 \%$ of the TMR was replaced by wheat and barley pellets (WBP) containing $50 \%$ ground wheat and $50 \%$ ground barley. Wheat and barley pellets that were not consumed within 10 min of feeding were placed into the rumen via the fistula. No hay other than that chopped in the TMR was provided during the days of the challenge. No DFM supplements were provided during rest. The TMR was formulated to meet the metabolizable protein, net energy, mineral, and vitamin requirements for lactating Holstein cows weighing 657 $\mathrm{kg}$ and producing $40 \mathrm{~kg}$ of $3.9 \% \mathrm{FCM}$ when consuming $25 \mathrm{~kg} / \mathrm{d}$ of DM (NRC, 2001).

Rumen $\mathrm{pH}$ was recorded every 10 min over a 24-h period, on d 17 of adaptation, on d 2 of SARA, and on d 6 of rest. The continuous recording system described in AlZahal et al. (2007) was used. The electrodes were calibrated with $\mathrm{pH} 4$ and $\mathrm{pH} 7$ buffer solutions before 
Table 1. Ingredients and composition of the TMR, wheat and barley pellets (WBP), and hay

\begin{tabular}{|c|c|c|c|}
\hline Item & TMR & $\mathrm{WBP}^{1}$ & Hay \\
\hline \multicolumn{4}{|l|}{ Ingredient (\% DM) } \\
\hline Hay & 3.4 & & \\
\hline Grass silage & 26.0 & & \\
\hline Corn silage & 26.3 & & \\
\hline Corn grain & 25.0 & & \\
\hline Soybean meal & 11.9 & & \\
\hline Beet pulp & 1.9 & & \\
\hline Protein supplement $^{2}$ & 2.4 & & \\
\hline Limestone & 0.5 & & \\
\hline Vitamin-mineral mixture $^{3}$ & 1.7 & & \\
\hline Megalac $^{4}$ & 0.8 & & \\
\hline \multicolumn{4}{|c|}{ Nutrient composition (\% of DM) } \\
\hline $\mathrm{CP}$ & 17.3 & 15.1 & 7.6 \\
\hline $\mathrm{aNDF}^{5}$ & 26.9 & 16.5 & 75.0 \\
\hline $\mathrm{ADF}$ & 19.6 & 8.4 & 47.0 \\
\hline NSC & 41.9 & 63.6 & 9.4 \\
\hline \multicolumn{4}{|c|}{${ }^{1}$ Wheat and barley pellets $(0.5 / 0.5)$. } \\
\hline \multicolumn{4}{|c|}{$\begin{array}{l}{ }^{2} \text { Protein supplement contained the following ingredients (\%): corn } \\
\text { distillers grain }(25) \text {, wheat distillers grain (15), canola meal (15), } \\
\text { SoyPLUS (45; West Central Cooperative, Ralston, IA). }\end{array}$} \\
\hline \multicolumn{4}{|c|}{$\begin{array}{l}{ }^{3} \text { Vitamin-mineral mixture contained the following major minerals }(\%) \text { : } \\
\mathrm{Ca}(9.5), \mathrm{P}(5.5), \mathrm{Mg}(5.5), \mathrm{Na}(13.0), \mathrm{Cl}(15.0), \mathrm{K}(1.4), \mathrm{S}(2.1) ; \text { the } \\
\text { following minor minerals }(\mathrm{mg} / \mathrm{kg}) \text { : Fe }(2,745), \mathrm{Mn}(2,065), \mathrm{Zn}(3,000) \text {, } \\
\mathrm{Cu}(495), \mathrm{I}(69), \mathrm{Co}(33), \mathrm{Se}(20) \text {; and the following vitamins (UI/kg): } \\
\text { vitamin A (501,859), vitamin D }(65,000) \text {, vitamin E }(2,600) \text {. }\end{array}$} \\
\hline \multicolumn{4}{|c|}{${ }^{4}$ Rumen-inert fat from palm oil. } \\
\hline${ }^{5}$ Neutral detergent fiber afte & & & \\
\hline
\end{tabular}

their introduction in the ventral sac of the rumen. On these same days, redox potential (Eh) was measured hourly from before morning feeding to $7 \mathrm{~h}$ after feeding. Redox potential was determined using a heavy-duty platinum submersible flat surface electrode (model no. PHE-7352-15-ORP, Omega, Laval, QC, Canada) inserted through the fistula and positioned in the ventral sac of the rumen, approximately $15 \mathrm{~cm}$ apart from the $\mathrm{pH}$ electrode. The electrode was connected to an intelligent conductivity and total dissolved solids $\mathrm{pH}$ meter (model PHH224, Omega). Because an $\mathrm{Ag}-\mathrm{AgCl}$ instead of a hydrogen reference electrode was used, Eh data were corrected according to Marden et al. (2005).

On the last day of adaptation (d 18), SARA (d 3), and rest (d 7), rumen content was sampled before morning feeding and after feeding for the determination of VFA and lactate concentrations (hourly up to $+7 \mathrm{~h}$ ); vitamin $\mathrm{B}_{12}(+3 \mathrm{~h})$; and total and LUB, bacterial profile, protozoa, and LPS ( $+6 \mathrm{~h})$. During SARA, time of sampling after feeding was relative to the first addition of WBP in the rumen, whereas prefeeding samples were taken before the TMR serving. Rumen content $(\sim 350$ $\mathrm{g}$ of solid and $1.5 \mathrm{~L}$ of liquid) was sampled through the rumen cannula from the ventral, posterior, and anterior sacs of the rumen. The content was squeezed through 4 layers of cheesecloth, and the filtrate was subsampled in duplicates and frozen $\left(-20^{\circ} \mathrm{C}\right)$ until analysis.
Samples for VFA and lactate were acidified before freezing, and concentrations were determined according to the procedure described in Chiquette et al. (2012) with the exception that $100 \mathrm{mg}$ of the ion-exchange resin was used for the removal of ammonia.

For vitamin $\mathrm{B}_{12}$ quantification, $50 \mathrm{~g}$ of rumen solid and $100 \mathrm{~mL}$ of strained rumen fluid were homogenized (2 times for $1 \mathrm{~min}$ ), with $30 \mathrm{~s}$ of rest on ice in between, in a blender (Waring Products Division, Commercial Blender, New Hartford, CT) to detach solid-associated bacteria. The homogenate was further treated for two 1-min cycles in a Polytron grinding mill (model no PT 10-35, Kinematica AG, Luzern, Switzerland), with 1-min rest on ice between cycles to open bacterial cells. Aliquots of $0.9 \mathrm{~g}$ were stored at $-80^{\circ} \mathrm{C}$. Thawed rumen sample $(1 \mathrm{~mL})$ was hydrolysed using $7 \mathrm{~mL}$ of extractive solution $\left(13 \mathrm{~g}\right.$ of $\mathrm{Na}_{2} \mathrm{HPO}_{4}, 12 \mathrm{~g}$ of citric acid, and $10 \mathrm{~g}$ of sodium metabisulfite per liter). A solution of $\mathrm{NaCN}$ $(1 M)$ was added in a proportion of $5 \mu \mathrm{L} / \mathrm{mL}$. Samples were autoclaved $\left(121^{\circ} \mathrm{C}, 10 \mathrm{~min}\right)$. After cooling in a water bath, $\mathrm{NaOH}$ solution $(3.3 N)$ was added to bring the $\mathrm{pH}$ to 6.2 to 6.5 , and the final volume was adjusted to $10 \mathrm{~mL}$ with distilled water. When necessary, samples were centrifuged $\left(1,854 \times g, 4^{\circ} \mathrm{C}\right)$ for $10 \mathrm{~min}$. Supernatant was kept frozen at $-20^{\circ} \mathrm{C}$ until analysis. Concentrations were determined in duplicate using a commercial kit (Simultrac $\mathrm{B}_{12}$, MP Biomedicals, Solon, $\mathrm{OH})$ with $200 \mu \mathrm{L}$ per assay.

Frozen filtered rumen fluid samples were treated as described in Chiquette (2009) for bacterial DNA extraction and purification. Total bacteria, S. ruminantium, and M. elsdenii were quantified by real-time PCR using an ABI 7500 Fast Real-Time system (Applied Biosystems, Foster City, CA). Each reaction mixture was run in triplicate in a volume of $10 \mu \mathrm{L}$ in optical reaction plates sealed with optical adhesive film (Applied Biosystems). Amplification reactions were carried out with Fast SYBR green PCR master mix (Applied Biosystems) mixed with the selected primer sets and $3 \mu \mathrm{L}$ of genomic DNA containing $\sim 0.2,9$, and $9 \mathrm{ng}$ for total bacteria, S. ruminantium, and M. elsdenii, respectively. Primer set for total bacteria is described in Maeda et al. (2003), whereas those for S. ruminantium and M. elsdenii are reported in Khafipour et al. (2009c). A concentration of $0.5 \mu M$ for each primer was used for total bacteria and $0.3 \mu M$ for $M$. elsdenii and $S$. ruminantium, respectively. Selenomonas ruminantium was grown in a broth medium (medium no. 602 from American type culture collection). Megasphaera elsdenii was grown in reinforced clostridia medium broth (Difco, Becton Dickinson, Mississauga, ON, Canada). Each culture was streaked over agar medium for purity check, and a single colony was picked for growth in the broth medium up to an optical density of 0.41 for $S$. 
ruminantium and 0.9 for $M$. elsdenii. Several dilutions of $S$. ruminantium and $M$. elsdenii were used for the standard curves. Cycling parameters for S. ruminantium and $M$. elsdenii are described in Chiquette et al. (2012). Several dilutions $\left(10^{1}\right.$ to $\left.10^{5}\right)$ of pooled rumenfluid DNA from adaptation, SARA, and rest were used for the reference standard curve of total bacteria. Amplification for total bacteria consisted of 1 cycle of $95^{\circ} \mathrm{C}$ $(20 \mathrm{~s}), 40$ cycles of denaturation at $95^{\circ} \mathrm{C}(15 \mathrm{~s})$, and annealing and extension at $61^{\circ} \mathrm{C}(30 \mathrm{~s})$ and $72^{\circ} \mathrm{C}(30$ $\mathrm{s})$. Amplification efficiencies were determined following the equation of Denman and McSweeney (2006) and varied from 96 to $102 \%$ for total bacteria, 83 to $92 \%$ for M. elsdenii, and 106 to $113 \%$ for S. ruminantium.

The bacterial community profile was characterized by a 16SrDNA-based fingerprinting method named amplicon length heterogeneity PCR (LH-PCR) using primers 27F and 355R (Suzuki et al., 1998), as previously described (Roy et al., 2009).

Total protozoa population was quantified by realtime PCR on purified DNA using the method described in Sylvester et al. (2004). Real-time PCR standard was generated as described in Sylvester et al. (2004). Polymerase chain reaction was performed with $1 \mathrm{ng}$ of genomic DNA using the Mastercycler gradient (Eppendorf, Mississauga, ON, Canada). The reaction volume was $25 \mu \mathrm{L}$ containing $12.5 \mathrm{pmol}$ of each primer, $0.5 \mu \mathrm{L}$ of deoxynucleotide triphosphates $(10 \mathrm{mM}), 1.5 \mu \mathrm{L}$ of $\mathrm{MgCl}_{2}(25 \mathrm{mM}), 1 \times \mathrm{PCR}$ buffer without $\mathrm{MgCl}_{2}$, and $0.125 \mu \mathrm{L}$ of Taq DNA polymerase $(5.0 \mathrm{U} / \mu \mathrm{L})$.

The quantification of protozoal DNA copies present in the extracted DNA from each sample was performed in triplicate using a StepOnePlus Real-time PCR systems (Applied Biosystems). Dilutions of DNA to $1 \mathrm{ng}$ from all samples were added to amplification reactions (10 $\mu \mathrm{L}$ ) containing 900 and $600 \mathrm{n} M$ of forward and reverse primers, respectively, and $5 \mu \mathrm{L}$ of $2 \times$ Fast SYBR Green Master Mix (Applied Biosystems). Cycling conditions were $95^{\circ} \mathrm{C}(20 \mathrm{~s}) ; 40$ cycles of $95^{\circ} \mathrm{C}(10 \mathrm{~s}), 55^{\circ} \mathrm{C}(10 \mathrm{~s})$, and $60^{\circ} \mathrm{C}(30 \mathrm{~s})$.

For rumen LPS analyses, $40 \mathrm{~mL}$ of filtered rumen fluid were transferred into $50-\mathrm{mL}$ sterile tubes and kept on ice until centrifugation $\left(10,000 \times g\right.$ at $4^{\circ} \mathrm{C}$ for 45 min). The supernatant was filtered through a $0.22-\mu \mathrm{m}$ LPS-free filter. Samples were stored in pyrogen-free glass tubes at $-20^{\circ} \mathrm{C}$ until analysis according to the method described in Gozho et al. (2005).

Blood samples for the determination of LPS-binding protein (LBP) and serum amyloid A (SAA) were collected by tail venipuncture in heparinized $10-\mathrm{mL}$ evacuated tubes (Fisher Scientific, Fairlawn, NJ). Samples were taken before morning feeding and $6 \mathrm{~h}$ after morning feeding on the last day of adaptation, SARA, and rest and processed according to Khafipour et al. (2009a). Plasma was divided into 2-mL aliquots and stored at $-20^{\circ} \mathrm{C}$ until analysis for LBP and SAA according to Gozho et al. (2005) and Khafipour et al. (2009a), respectively.

Feed intake was recorded daily, and samples of TMR, hay, and WBP were collected weekly and pooled by feeding phase (adaptation, SARA, rest) within each experimental period. Feed samples were sent to a private laboratory (Agri-analyze, Sherbrooke, QC, Canada) for the determination of $\mathrm{CP}, \mathrm{NDF}, \mathrm{ADF}$, and NSC using near-infrared spectroscopy. Chemical composition of the TMR, WBP, and hay is presented in Table 1. Cows were milked twice a day, and milk yield was recorded daily. Milk samples were taken on 4 consecutive milkings at the end of the adaptation and rest phases and on each milking during SARA for the analysis of milk fat, protein, lactose, urea-N, and somatic cell counts. Milk composition was determined as described in Chiquette et al. (2012).

\section{Statistical Analyses}

Variables were summarized to one data point per cow per period within each phase and time of sampling relative to feeding (in the case of vitamin $\mathrm{B}_{12}$, bacterial, and protozoal populations). Data were statistically analyzed according to a $4 \times 4$ Latin square design balanced for residual effects, with cow, period, and treatment as fixed factors. Phases and pre- and postfeeding times were analyzed as repeated measurements. The MIXED procedure of SAS (SAS Institute Inc., 2002) was used for all analyses. For all variables, adaptation and rest phases were compared with SARA phase, with the exception of rumen LPS and plasma LBP and SAA for which only samples from adaptation and SARA were analyzed. When the effect of DFM was significant $(P \leq$ 0.05), EFSC was further compared with CON, EF, and EFLL using a Dunnett correction. For bacterial and protozoal populations, and vitamin $\mathrm{B}_{12}$ concentrations, results from before and after feeding were compared during adaptation, SARA, and rest. Bacterial and protozoal population data were log-transformed to obtain a normal distribution and homogeneous residual error and reconverted to nanograms per milliliter and copies per nanogram of DNA, respectively. An angular transformation was used for the analyses of bacterial ratios. Least squares means are associated with confidence intervals instead of SEM, for these variables. Significance was declared at $P \leq 0.05$, and trends were accepted if $P \leq 0.10$.

For analyses of bacterial community profile, nonmetric multidimensional scaling ordination and multiresponse permutation procedure were performed using the PC-ORD version 6 software (MjM Software Design 
Inc., Gleneden Beach, OR) on LH-PCR data converted into rank-transformed Bray-Curtis distance matrices. These multivariate statistics (McCune et al., 2002) were performed to interpret changes in the bacterial community structure by SARA challenge or by DFM treatment. Indicator species analysis (Dufrêne and Legendre, 1997) was performed on LH-PCR relative abundance data using the PC-ORD software. Indicator species analysis was done to determine which $\mathrm{LH}-$ PCR amplicons are indicative of LH-PCR differences observed among groups.

\section{RESULTS AND DISCUSSION}

\section{Ruminal $\mathrm{pH}$ and Eh}

Subacute ruminal acidosis was induced successfully, with $\mathrm{pH}$ characteristics similar to those found by previous authors (Krause and Oetzel, 2005). Minimum $\mathrm{pH}$ was lower during SARA when compared with adaptation (Table 2). Although mean and median $\mathrm{pH}$ were numerically lower during SARA (5.88 and 5.90, respectively) compared with adaptation (6.02 and 5.99, respectively), they were only significantly different when compared with rest (6.13). Maximum $\mathrm{pH}$ was not affected by feeding phase. Percent of the 24-h period with $\mathrm{pH}<6.0$ was similar between adaptation and SARA $(51 \%)$ and tended to be greater than during rest $(33 \% ; P=0.07)$. Time with $\mathrm{pH}<5.5$ tended $(P$ $=0.07)$ to be greater during SARA $(24 \%)$ than during adaptation $(11 \%)$ but was significantly greater when compared with rest $(8 \% ; P=0.03)$. Time with $\mathrm{pH}<5.2$ was greater during SARA (8\%) than during adaptation $(0 \%)$ or rest $(0 \% ; P<0.001)$.

Some DFM affected rumen $\mathrm{pH}$ even during adaptation (Table 3). Median pH with EFSC (6.21) was greater than that with $\mathrm{EF}(5.76 ; P<0.01)$ or EFLL (5.97; $P=0.05)$ and tended to be greater than that with $\mathrm{CON}(6.03 ; P=0.10)$. Percent $\mathrm{pH}$ values $<5.5$ with EFSC $(0.61 \%)$ was lower than that with $\mathrm{EF}(21 \%$; $P=0.02)$ and tended to be lower than that with EFLL $(11.9 \% ; P=0.08)$ or CON (11.2\%; $P=0.09)$.

During SARA, time spent with $\mathrm{pH}<6.0$ tended to be lower with EFSC (56\%) than with EF (64\%; $P=$ $0.08)$ and greater than with EFLL $(46 \% ; P=0.07)$. Although mean and median $\mathrm{pH}$ were numerically superior with EFSC (5.94 and 5.98, respectively) compared with CON (5.82 and 5.81, respectively), they did not reach significance $(P=0.11$ and 0.13 , respectively). Results during rest clearly show the absence of residual DFM effects after their withdrawal.

The combination EFSC proved to be superior to EF alone in the maintenance of greater $\mathrm{pH}$ values when dairy cows were submitted to a high-concentrate diet or a SARA challenge. It is possible that this effect is due to the yeast alone providing nutrients to specific bacterial populations. Differences in $\mathrm{pH}$ between $\mathrm{CON}$ and EFSC were less pronounced than in previous studies (Chiquette, 2009; Chiquette et al., 2012) where SARA conditions obtained following the challenge were more severe.

During SARA, similar $\mathrm{pH}$ results were obtained with EFSC or EFLL. Based on Eh results (below), pH improvements with EFSC and EFLL during SARA could not be attributed to their $\mathrm{O}_{2}$-scavenging capacity.

The Eh was greater during SARA $(-150 \mathrm{mV})$ than during adaptation $(-180 \mathrm{mV} ; P<0.001)$ or rest $(-176$ $\mathrm{mV} ; P=0.04$; Table 2). Mathieu et al. (1996) reported an inverse relationship between $\mathrm{pH}$ and Eh when both were measured in control fistulated sheep from 0 to 7 $\mathrm{h}$ after feeding. The $\mathrm{pH}$ decreased from 6.6 to 5.85 in the hours following feeding and Eh increased $(+30 \mathrm{mV}$;

Table 2. Effect of feeding phases on rumen $\mathrm{pH}$ over a 24-h period and on redox potential (Eh) measured hourly ${ }^{1}$

\begin{tabular}{|c|c|c|c|c|c|c|c|}
\hline \multirow[b]{2}{*}{ Parameter } & \multirow[b]{2}{*}{ Adaptation (A) } & \multirow[b]{2}{*}{ SARA (S) } & \multirow[b]{2}{*}{ Rest (R) } & \multirow[b]{2}{*}{ SEM } & \multicolumn{3}{|c|}{ Probability ( $P$-value) } \\
\hline & & & & & Phases & A vs. $\mathrm{S}$ & $\mathrm{R}$ vs. $\mathrm{S}$ \\
\hline \multicolumn{8}{|l|}{$\mathrm{pH}^{2}$} \\
\hline Minimum & 5.50 & 5.10 & 5.60 & 0.07 & $<0.01$ & $<0.01$ & $<0.01$ \\
\hline Maximum & 6.63 & 6.68 & 6.62 & 0.05 & 0.63 & 0.35 & 0.45 \\
\hline Mean & 6.02 & 5.88 & 6.13 & 0.05 & 0.04 & 0.23 & 0.03 \\
\hline Median & 5.99 & 5.90 & 6.13 & 0.05 & 0.03 & 0.46 & 0.03 \\
\hline \multicolumn{8}{|l|}{$\mathrm{pH}^{3}(\%)$} \\
\hline $\mathrm{pH}<6.0$ & 46.4 & 55.2 & 33.4 & 5.55 & 0.05 & 0.52 & 0.07 \\
\hline $5.5<\mathrm{pH}<6.0$ & 35.3 & 31.2 & 25.2 & 3.64 & 0.15 & 0.69 & 0.49 \\
\hline $\mathrm{pH}<5.5$ & 11.1 & 24.0 & 8.2 & 3.27 & 0.05 & 0.07 & 0.03 \\
\hline $5.2<\mathrm{pH}<5.5$ & 11.1 & 15.9 & 8.1 & 2.90 & 0.31 & 0.49 & 0.22 \\
\hline $\mathrm{pH}<5.2$ & 0.00 & 8.11 & 0.00 & 1.19 & $<0.001$ & $<0.001$ & $<0.001$ \\
\hline $\operatorname{Eh}(\mathrm{mV})$ & -180 & -150 & -176 & 9.12 & $<0.001$ & $<0.001$ & 0.04 \\
\hline
\end{tabular}

${ }^{1}$ Redox potential was measured $1 \mathrm{~h}$ before feeding and hourly during $7 \mathrm{~h}$ after feeding on the day before rumen sampling.

${ }^{2} \mathrm{pH}$ was measured every $10 \mathrm{~min}$ over a 24 -h period on the day before rumen sampling.

${ }^{3}$ Percent of the 24 -h period with $\mathrm{pH}$ values within the specified range. 
Table 3. Effect of direct-fed microbials on rumen $\mathrm{pH}$ over a 24-h period and on redox potential (Eh) measured hourly ${ }^{1}$ during adaptation, SARA, and rest

\begin{tabular}{|c|c|c|c|c|c|c|c|c|c|}
\hline \multirow[b]{2}{*}{ Item } & \multicolumn{4}{|c|}{ Treatment $^{2}$} & \multirow[b]{2}{*}{ SEM } & \multicolumn{4}{|c|}{ Probability ( $P$-value) } \\
\hline & $\mathrm{CON}$ & $\mathrm{EF}$ & EFSC & EFLL & & $\begin{array}{l}\text { Direct-fed } \\
\text { microbials }\end{array}$ & $\begin{array}{c}\text { EFSC } \\
\text { vs. CON }\end{array}$ & $\begin{array}{l}\text { EFSC } \\
\text { vs. EF }\end{array}$ & $\begin{array}{c}\text { EFSC } \\
\text { vs. EFLL }\end{array}$ \\
\hline \multicolumn{10}{|l|}{$\begin{array}{l}\text { Adaptation } \\
\mathrm{pH}^{3}\end{array}$} \\
\hline Minimum & 5.56 & 5.48 & 5.51 & 5.46 & 0.06 & 0.69 & 0.87 & 0.96 & 0.90 \\
\hline Maximum & 6.64 & 6.61 & 6.61 & 6.66 & 0.03 & 0.74 & 0.83 & 1.00 & 0.68 \\
\hline \multicolumn{10}{|l|}{$\mathrm{pH}^{4}(\%)$} \\
\hline $\mathrm{pH}<6.0$ & 41.7 & 66.7 & 26.2 & 50.9 & 8.86 & 0.16 & 0.56 & 0.10 & 0.29 \\
\hline $5.5<\mathrm{pH}<6.0$ & 30.5 & 46.0 & 25.6 & 39.1 & 7.10 & 0.36 & 0.93 & 0.27 & 0.51 \\
\hline $\mathrm{pH}<5.5$ & 11.2 & 20.7 & 0.61 & 11.9 & 2.18 & 0.03 & 0.09 & 0.02 & 0.08 \\
\hline $5.2<\mathrm{pH}<5.5$ & 11.2 & 20.7 & 0.61 & 11.9 & 2.18 & 0.03 & 0.09 & 0.02 & 0.08 \\
\hline $\mathrm{pH}<5.2$ & 0.00 & 0.00 & 0.00 & 0.00 & - & - & - & - & - \\
\hline Eh (mV) & -182 & -187 & -168 & -182 & 6.56 & 0.28 & 0.34 & 0.19 & 0.34 \\
\hline Median & 5.81 & 5.80 & 5.98 & 6.03 & 0.04 & 0.06 & 0.13 & 0.12 & 0.71 \\
\hline \multicolumn{10}{|l|}{$\mathrm{pH}(\%)$} \\
\hline $\mathrm{pH}<6.0$ & 54.7 & 64.2 & 55.5 & 46.4 & 1.67 & 0.02 & 0.96 & 0.08 & 0.07 \\
\hline $5.5<\mathrm{pH}<6.0$ & 17.3 & 39.4 & 38.0 & 29.9 & 7.04 & 0.29 & 0.26 & 1.00 & 0.78 \\
\hline $\mathrm{pH}<5.5$ & 37.4 & 24.8 & 17.5 & 16.4 & 6.05 & 0.24 & 0.21 & 0.75 & 1.00 \\
\hline $5.2<\mathrm{pH}<5.5$ & 18.9 & 20.9 & 14.0 & 9.89 & 4.11 & 0.39 & 0.76 & 0.58 & 0.83 \\
\hline $\mathrm{pH}<5.2$ & 18.5 & 3.90 & 3.55 & 6.54 & 4.65 & 0.27 & 0.22 & 1.00 & 0.94 \\
\hline Eh $(\mathrm{mV})$ & -141 & -163 & -147 & -150 & 13.9 & 0.72 & 0.98 & 0.75 & 1.00 \\
\hline \multicolumn{10}{|l|}{ Rest } \\
\hline \multicolumn{10}{|l|}{$\mathrm{pH}$} \\
\hline Minimum & 5.55 & 5.68 & 5.54 & 5.62 & 0.13 & 0.85 & 1.00 & 0.80 & 0.95 \\
\hline Maximum & 6.62 & 6.70 & 6.52 & 6.63 & 0.05 & 0.26 & 0.47 & 0.17 & 0.41 \\
\hline Mean & 6.12 & 6.15 & 6.08 & 6.16 & 0.07 & 0.85 & 0.97 & 0.82 & 0.78 \\
\hline Median & 6.10 & 6.10 & 6.15 & 6.18 & 0.08 & 0.88 & 0.96 & 0.95 & 0.99 \\
\hline
\end{tabular}

${ }^{1}$ Redox potential was measured $1 \mathrm{~h}$ before feeding and hourly during $7 \mathrm{~h}$ after feeding on the day before rumen sampling.

${ }^{2} \mathrm{CON}=$ control; $\mathrm{EF}=$ Enterococcus faecium [mixture of 3 strains: E. faecium $1\left(1.2 \times 10^{9} \mathrm{cfu} / \mathrm{g}\right)$, E. faecium $2\left(1.2 \times 10^{9} \mathrm{cfu} / \mathrm{g}\right)$, and E. faecium $\left.3\left(1.3 \times 10^{7} \mathrm{cfu} / \mathrm{g}\right)\right] ; \mathrm{EFSC}=\mathrm{EF}+$ Saccharomyces cerevisiae $\left(1 \times 10^{9} \mathrm{cfu} / \mathrm{g}\right) ; \mathrm{EFLL}=\mathrm{EF}+$ Lactococcus lactis DSM $11037\left(2.8 \times 10^{9} \mathrm{cfu} / \mathrm{g}\right)$. ${ }^{3} \mathrm{pH}$ was measured every $10 \mathrm{~min}$ over a 24 -h period on the day before rumen sampling.

${ }^{4}$ Percent of the 24 -h period with $\mathrm{pH}$ values within the specified range.

from -330 to $-300 \mathrm{mV}$ ). The increase in Eh observed in the present study from adaptation to SARA was comparable to that reported by Mathieu et al. (1996) from 0 to $7 \mathrm{~h}$ after feeding.

Direct-fed microbials had no effects on Eh during each experimental phase (Table 3). Treatments selected for their superior $\mathrm{O}_{2}$-scavenging activity (EFSC and EFLL) did not prevent the decrease in Eh during SARA. Mathieu et al. (1996) reported lower Eh values with addition of Saccharomyces cerevisiae (SC) to sheep $(-312.8 \mathrm{mV}$, on average from 0 to $7 \mathrm{~h}$ after feeding) compared with CON $(-292.7 \mathrm{mV})$. Krizova et al. (2011) also reported lower Eh $(-223 \mathrm{mV})$, with a particularly small SEM (0.24), when SC was given to 4 dry Holstein cows, compared with CON $(-210 \mathrm{mV})$.

\section{Rumen VFA, Lactate, and Vitamin $B_{12}$}

Total VFA concentration increased during SARA versus adaptation (Table 4). The proportion of acetate and isoacids decreased during SARA, whereas the proportion of propionate and butyrate increased compared with adaptation. Similarly, results from previous studies show increased concentration of total VFA and 
Table 4. Effect of feeding phases on molar proportions ( $\mathrm{mol} / 100 \mathrm{~mol}$ ) of individual VFA and concentration of total VFA (mM)

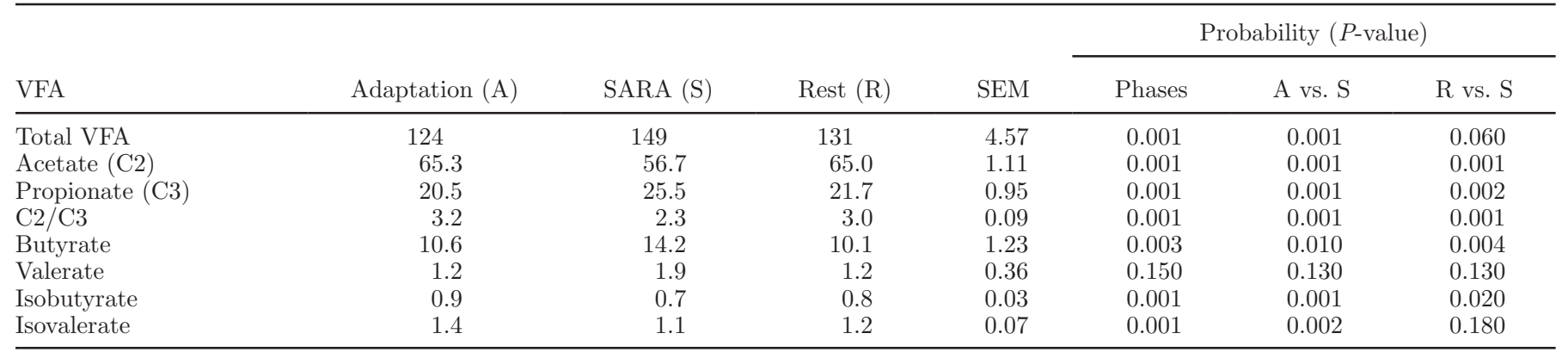

increased proportions of propionate and butyrate during SARA compared with the control period, whereas proportions of acetate and isoacids decreased in SARA versus control (Khafipour et al., 2009a; Chiquette et al., 2012). Total VFA concentration tended to be lower during rest compared with SARA. For most of the VFA, the proportions were back to adaptation levels during rest, with the exception of isovalerate, which did not differ between feeding phases. In accordance with previous results, DFM did not affect total VFA concentration or proportion of individual VFA (Chiquette, 2009; Chiquette et al., 2012). Lactate profile was extremely variable among dairy cows; only 2 of the 4 cows had increased lactate concentration over $5 \mathrm{~m} M$ during SARA. These data precluded statistical analyses.

The interaction between feeding phases and time of sampling tended to be significant $(P=0.06)$ for vitamin $\mathrm{B}_{12}$ concentrations in the rumen. Before and after feeding, concentrations of vitamin $\mathrm{B}_{12}$ in the rumen decreased during SARA (128.8 and $110.1 \mathrm{ng} / \mathrm{g}$, respectively) compared with adaptation levels (160.3 and $131.4 \mathrm{ng} / \mathrm{g}$, respectively; $P \leq 0.02)$ and tended to recover to adaptation levels during rest (147.4 and $126.2 \mathrm{ng} / \mathrm{g}$, respectively; $P \leq 0.09$ ). Across feeding phases, vitamin $\mathrm{B}_{12}$ concentrations were lower after feeding (123 ng/g) compared with before feeding (146 $\mathrm{ng} / \mathrm{g} ; P=0.002)$. Direct-fed microbials had no effect on vitamin $\mathrm{B}_{12}$ concentrations during adaptation (Table 5); however, during SARA and postfeeding, vitamin $\mathrm{B}_{12}$ concentrations were greater when the animals received EFSC (134.5 ng/g) compared with EF (99.6 ng/g) and tended to be greater compared with CON (101.2 ng/g) or EFLL (104.9 ng/g). During rest, prefeed vitamin $\mathrm{B}_{12}$ concentration was still greater with EFSC $(166.5 \mathrm{ng} / \mathrm{g})$ compared with CON (132.3 ng/g) and tended to be greater compared with EF (140.2 ng/g).

Vitamin $\mathrm{B}_{12}$, which is not present in animal feed, is exclusively produced by bacteria (mainly P. freudenreichii and S. ruminantium) in the rumen (Dryden et al., 1962). These early findings were corroborated more recently by Anderson et al. (2001) and Piao et al. (2004). In spite of the synthesis of vitamin $B_{12}$ in the rumen, Girard and Desrochers (2010) reported increased glucose flux across portal-drained viscera when dairy cows received a dietary supplement of this vitamin, indicating that requirements for vitamin $\mathrm{B}_{12}$ of high-producing dairy cows are not totally met by rumen bacterial synthesis.

Because the concentration of $S$. ruminantium increased during SARA in the present study, we would

Table 5. Effect of direct-fed microbials and time of sampling on vitamin $\mathrm{B}_{12}$ concentrations (ng/g of rumen content) during adaptation, SARA, and rest

\begin{tabular}{|c|c|c|c|c|c|c|c|c|c|}
\hline \multirow[b]{2}{*}{ Item } & \multicolumn{4}{|c|}{ Treatment $^{1}$} & \multirow[b]{2}{*}{ SEM } & \multicolumn{4}{|c|}{ Probability ( $P$-value) } \\
\hline & $\mathrm{CON}$ & $\mathrm{EF}$ & EFSC & EFLL & & $\begin{array}{l}\text { Direct-fed } \\
\text { microbials }\end{array}$ & $\begin{array}{c}\text { EFSC } \\
\text { vs. CON }\end{array}$ & $\begin{array}{c}\text { EFSC } \\
\text { vs. EF }\end{array}$ & $\begin{array}{c}\text { EFSC } \\
\text { vs. EFLL }\end{array}$ \\
\hline Before feeding & 151.5 & 162.0 & 168.9 & 158.7 & 15.2 & 0.67 & 0.50 & 0.92 & 0.81 \\
\hline $3 \mathrm{~h}$ After feeding & 125.9 & 140.2 & 137.3 & 122.3 & 14.8 & 0.51 & 0.73 & 0.99 & 0.57 \\
\hline \multicolumn{10}{|l|}{ SARA } \\
\hline \multicolumn{10}{|l|}{ Rest } \\
\hline Before feeding & 132.3 & 140.2 & 166.5 & 150.6 & 13.3 & 0.04 & 0.02 & 0.06 & 0.27 \\
\hline $3 \mathrm{~h}$ After feeding & 113.1 & 134.2 & 129.5 & 128.0 & 13.9 & 0.31 & 0.36 & 0.94 & 1.00 \\
\hline
\end{tabular}

${ }^{1} \mathrm{CON}=$ control; $\mathrm{EF}=$ Enterococcus faecium [mixture of 3 strains: E. faecium $1\left(1.2 \times 10^{9} \mathrm{cfu} / \mathrm{g}\right)$, E. faecium $2\left(1.2 \times 10^{9} \mathrm{cfu} / \mathrm{g}\right)$, and E. faecium $\left.3\left(1.3 \times 10^{7} \mathrm{cfu} / \mathrm{g}\right)\right] ; \mathrm{EFSC}=\mathrm{EF}+$ Saccharomyces cerevisiae $\left(1 \times 10^{9} \mathrm{cfu} / \mathrm{g}\right) ; \mathrm{EFLL}=\mathrm{EF}+$ Lactococcus lactis DSM $11037\left(2.8 \times 10^{9} \mathrm{cfu} / \mathrm{g}\right)$. 
have also expected increased concentration of vitamin $\mathrm{B}_{12}$ concentration during SARA. Possibly other species of vitamin $\mathrm{B}_{12}$-producing bacteria were negatively affected during SARA or the growth of vitamin $\mathrm{B}_{12}-$ utilizing bacteria was stimulated during SARA. However, when cows were supplemented with EFSC, rumen vitamin $\mathrm{B}_{12}$ concentrations did not decrease during SARA, suggesting that EFSC either stimulated some vitamin $\mathrm{B}_{12}$-producing bacteria or prevented their disappearance from the rumen because of higher rumen $\mathrm{pH}$.

\section{Total Bacteria and Lactate-Utilizing Bacteria}

The interaction between time of sampling and feeding phase was significant for total bacteria $(P=0.02)$ and for $S$. ruminantium expressed in nanograms per milliliter $(P=0.001)$ or as percent of total bacteria $(P=0.01)$. Total bacterial DNA in the rumen was not affected by feeding phase in samples collected before feeding (Table 6); however, $6 \mathrm{~h}$ after feeding it increased during SARA $(16,995 \mathrm{ng} / \mathrm{mL}$ of rumen fluid) compared with adaptation $(7,777 \mathrm{ng} / \mathrm{mL} ; P=0.001)$ and rest $(10,471 \mathrm{ng} / \mathrm{mL} ; P=0.02)$. Selenomonas ruminantium DNA, expressed as nanograms per milliliter of rumen fluid or as ratio over total bacterial DNA, also increased during SARA compared with adaptation $(P \leq$ $0.01)$ and rest $(P \leq 0.01)$. As opposed to total bacterial DNA, this increase during SARA was observed in both prefeeding and postfeeding samples but was much more pronounced in the postfeeding samples. Megasphaera elsdenii was only detected $(1,600 \mathrm{ng} / \mathrm{mL})$ in one cow, when under the CON treatment, in the 6 -h postfeeding samples during SARA (data not shown).

It is common to observe increased concentration of total bacteria with increased provision of nonstructural carbohydrates or when inducing SARA (Nagaraja and Titgemeyer, 2007). Generally, the low concentration of lactate observed under these circumstances is attribut- able to high prevalence of LUB such as M. elsdenii and S. ruminantium (Tajima et al., 2000). In the present study, apparently most of the lactate was metabolized by the latter bacterial species. Indeed, M. elsdenii was undetectable in the rumen of most cows, whereas $S$. ruminantium DNA was more than 20 times greater during SARA than during adaptation. Megasphaera elsdenii was observed in previous studies (Chiquette, 2009; Chiquette et al., 2012) where SARA challenge was more severe, leading to lower $\mathrm{pH}$ values and the presence of lactate, although at low levels (0.63 and $1.31 \mathrm{~m} M$, respectively).

Direct-fed microbials had no effect on the quantity of total bacterial DNA or S. ruminantium DNA (data not shown). This does not support the in vitro observation of Newbold et al. (1996) on increased bacterial population with increasing activity of oxygen scavenging.

\section{Bacterial Community Profile}

Profiles of rumen bacterial populations based on LHPCR method formed 2 distinct groups when comparing the adaptation versus the SARA period $(P=0.001$; Figure 1). An indicator species analysis showed that 35 LH-PCR amplicons out of 69 were modified by the feeding phase (data not shown). Eleven of these were more abundant, frequent, or both during SARA, whereas 24 were more abundant, frequent, or both during adaptation. Bacterial community profiles were much more scattered during SARA than during adaptation. This is representative of a greater ruminal instability and variability among animals due to a greater acidic environment prevailing in the rumen during SARA than during adaptation.

When comparing bacterial community profiles with EFSC versus each other treatment during adaptation and SARA, 5 LH-PCR amplicons, out of 69 , stood out significantly, and the amplicons that stood out were

Table 6. Effect of feeding phases on bacterial DNA concentration (ng/mL of rumen fluid) and proportion (\%) of Selenomonas ruminantium relative to total bacteria, in the rumen before and after feeding

\begin{tabular}{|c|c|c|c|c|c|c|c|}
\hline \multirow[b]{2}{*}{ Time of sampling } & \multirow[b]{2}{*}{ Adaptation (A) } & \multirow[b]{2}{*}{ SARA (S) } & \multirow[b]{2}{*}{ Rest (R) } & \multirow[b]{2}{*}{ SEM } & \multicolumn{3}{|c|}{ Probability ( $P$-value) } \\
\hline & & & & & Phases & A vs. S & R vs. $\mathrm{S}$ \\
\hline \multicolumn{8}{|c|}{ Total bacteria $(\mathrm{ng} / \mathrm{mL})$} \\
\hline Before feeding & 11,875 & 16,670 & 14,156 & 1,866 & 0.190 & NS & NS \\
\hline $6 \mathrm{~h}$ After feeding & 7,777 & 16,995 & 10,471 & 1,920 & 0.001 & 0.001 & 0.020 \\
\hline \multicolumn{8}{|c|}{ S. ruminantium $(\mathrm{ng} / \mathrm{mL})$} \\
\hline Before feeding & 19.8 & 80.2 & 14.5 & 16.2 & 0.002 & 0.004 & 0.002 \\
\hline Before feeding & $0.16[0.12-0.20]$ & $0.51[0.29-0.78]$ & $0.09[0.06-0.12]$ & - & 0.001 & 0.010 & 0.010 \\
\hline $6 \mathrm{~h}$ After feeding & $0.14[0.11-0.18]$ & $1.62[0.74-2.82]$ & $0.12[0.09-0.15]$ & - & 0.001 & 0.001 & 0.001 \\
\hline
\end{tabular}

${ }^{1}$ Confidence intervals (in brackets) are presented instead of SEM as data needed to be log-transformed because data distribution did not follow a normal curve. 


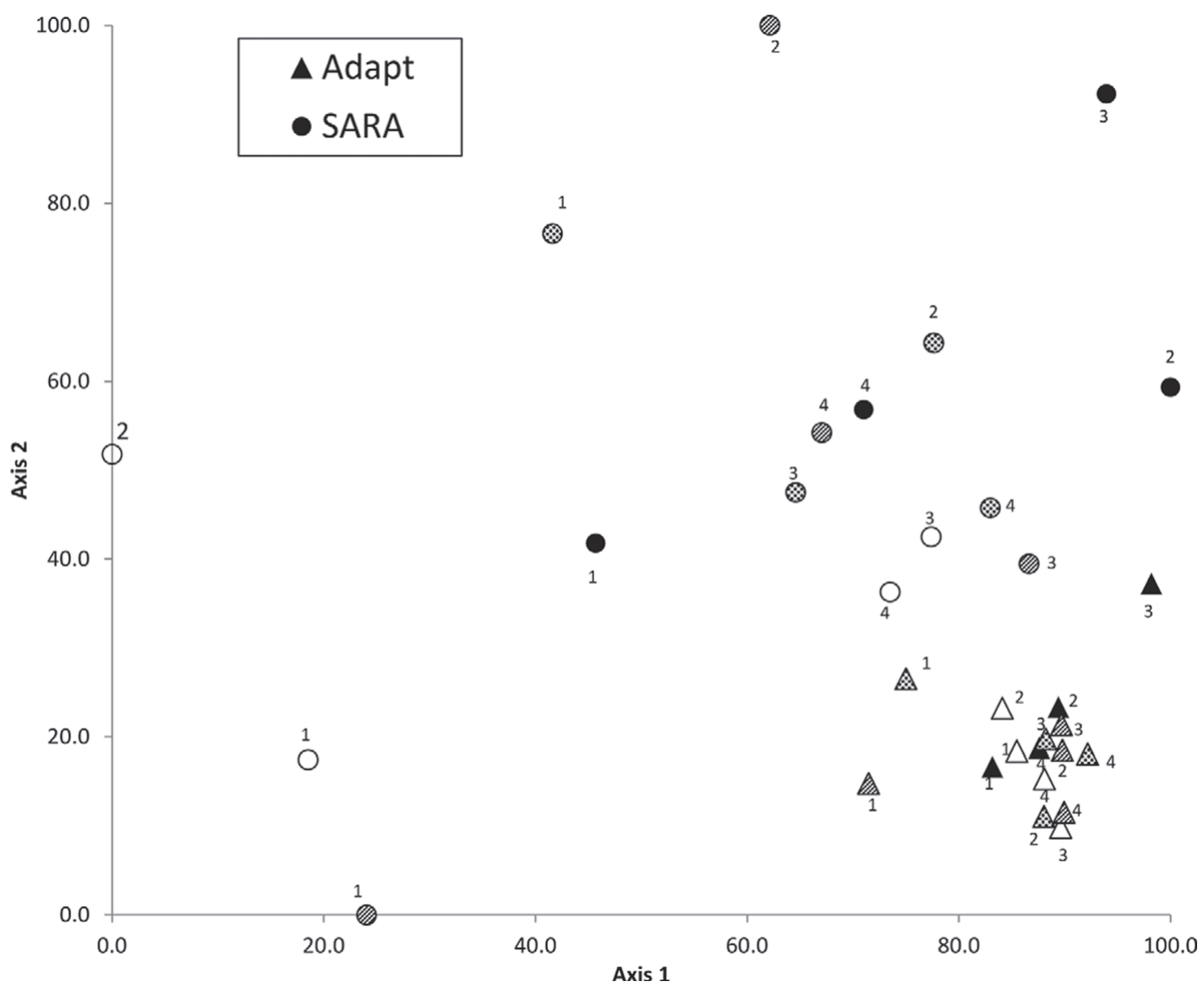

Figure 1. Changes in bacterial-community structure between adaptation (triangles) and SARA (circles) determined by nonmetric multidimensional scaling. Bacterial-community structure of each cow is identified 1 to 4 , respectively. Treatments are represented by the following fillings of symbols: open $=$ control; hachured $=$ Enterococcus faecium [mixture of 3 strains: E. faecium $1\left(1.2 \times 10^{9} \mathrm{cfu} / \mathrm{g}\right)$, E. faecium 2 (1.2 $\left.\times 10^{9} \mathrm{cfu} / \mathrm{g}\right)$, and E. faecium $\left.3\left(1.3 \times 10^{7} \mathrm{cfu} / \mathrm{g}\right)\right]$; dotted $=$ E. faecium and Saccharomyces cerevisiae $\left(1 \times 10^{9} \mathrm{cfu} / \mathrm{g}\right) ; \mathrm{black}=E$. faecium and Lactococcus lactis DSM $11037\left(2.8 \times 10^{9} \mathrm{cfu} / \mathrm{g}\right)$. The coefficients of determination for the correlations between ordination distances and distances in the original space were 0.434 and 0.477 for axis 1 and 2 , respectively.

of different sizes between all DFM comparisons within adaptation and SARA. It would be interesting to sequence these amplicons in the scope of further studies. Silberberg et al. (2013) used capillary electrophoresissingle-stranded conformation polymorphism analysis and reported a distinct bacterial-community structure in sheep between periods of acidosis challenge and resting periods. Single-stranded conformation polymorphism analysis suggested that SC increased bacterial diversity.

\section{Protozoa}

The number of copies of protozoa per nanogram of DNA decreased during SARA $(3,249)$ compared with adaptation $(20,118)$ or rest $(11,128 ; P \leq 0.01$; Figure $2)$. It has been well established that the protozoa population declines as rumen acidity increases. Owens et al. (1998) attributed it to the washing out of protozoa in absence of a fibrous mat, which plays an important role in the sequestration and replication of protozoa. Also, previous studies (Slyter, 1976) showed that low pH together with high osmotic pressure could have a direct toxic effect on protozoa. Treatment had an effect at the 6-h sampling $(P=0.03)$ and a tendency $(P=0.06)$ at the 0 -h sampling. However, none of the preestablished comparisons with EFSC (EFSC vs. EF; EFSC vs. EFLL; EFSC vs. CON) were significant. The greater protozoa population observed with EFLL and EFSC during SARA compared with $\mathrm{EF}$ or CON is probably directly linked to the greater $\mathrm{pH}$ values recorded with these same DFM.

\section{Rumen LPS, Plasma LBP, and SAA}

Only 6-h-postfeeding samples on the last day of adaptation and SARA were analyzed for these variables. Rumen LPS concentration was greater during SARA 

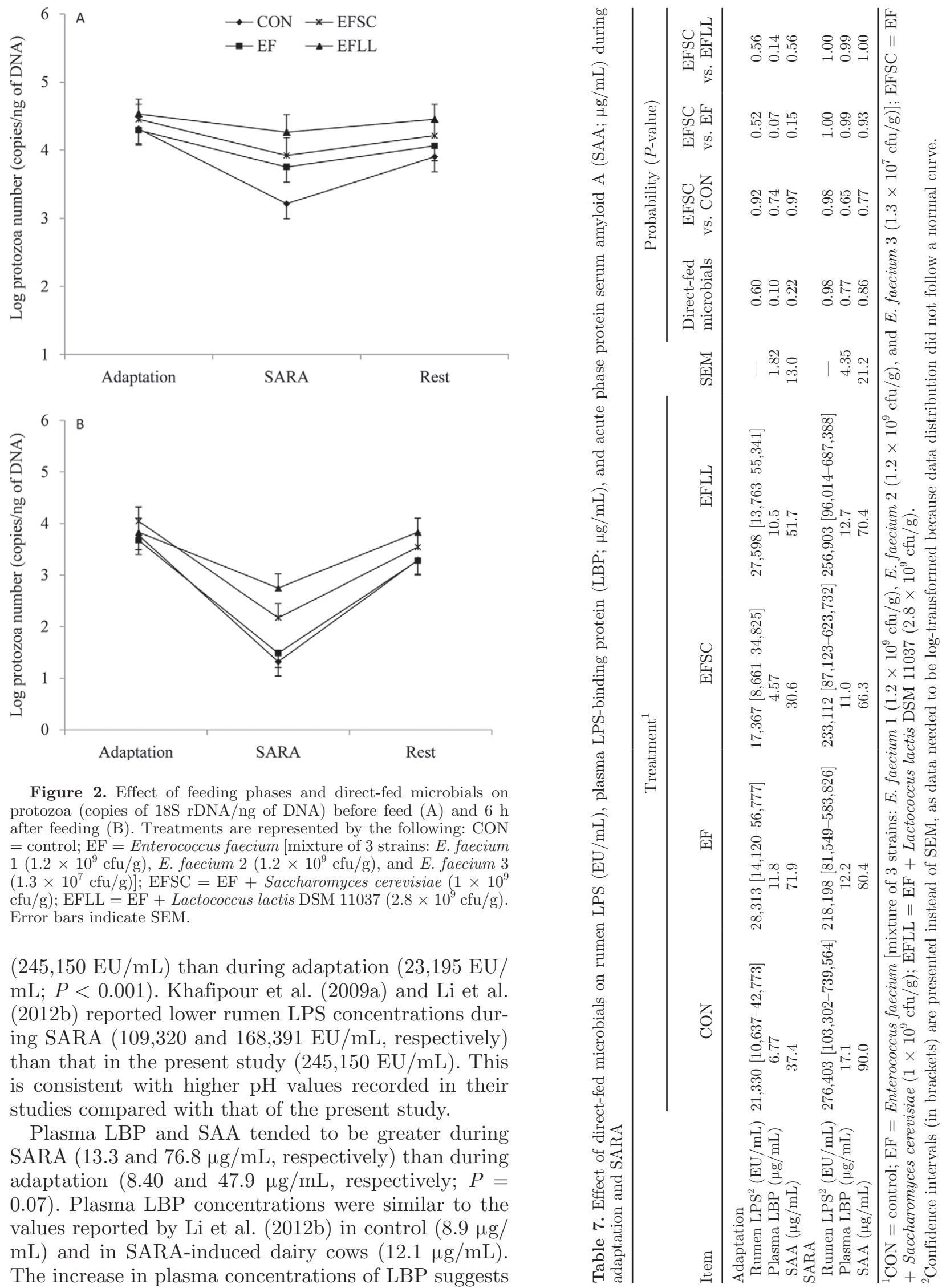

Figure 2. Effect of feeding phases and direct-fed microbials on protozoa (copies of $18 \mathrm{~S} \mathrm{rDNA} / \mathrm{ng}$ of DNA) before feed (A) and $6 \mathrm{~h}$ after feeding (B). Treatments are represented by the following: CON $=$ control $; \mathrm{EF}=$ Enterococcus faecium [mixture of 3 strains: $E$. faecium $1\left(1.2 \times 10^{9} \mathrm{cfu} / \mathrm{g}\right)$, E. faecium $2\left(1.2 \times 10^{9} \mathrm{cfu} / \mathrm{g}\right)$, and E. faecium 3 $\left.\left(1.3 \times 10^{7} \mathrm{cfu} / \mathrm{g}\right)\right] ;$ EFSC $=\mathrm{EF}+$ Saccharomyces cerevisiae $\left(1 \times 10^{9}\right.$ $\mathrm{cfu} / \mathrm{g}) ; \mathrm{EFLL}=\mathrm{EF}+$ Lactococcus lactis DSM $11037\left(2.8 \times 10^{9} \mathrm{cfu} / \mathrm{g}\right)$. Error bars indicate SEM.

$(245,150 \mathrm{EU} / \mathrm{mL})$ than during adaptation $(23,195 \mathrm{EU} /$ $\mathrm{mL} ; P<0.001)$. Khafipour et al. (2009a) and Li et al. (2012b) reported lower rumen LPS concentrations during SARA (109,320 and 168,391 $\mathrm{EU} / \mathrm{mL}$, respectively) than that in the present study $(245,150 \mathrm{EU} / \mathrm{mL})$. This is consistent with higher $\mathrm{pH}$ values recorded in their studies compared with that of the present study.

Plasma LBP and SAA tended to be greater during SARA (13.3 and $76.8 \mu \mathrm{g} / \mathrm{mL}$, respectively) than during adaptation $(8.40$ and $47.9 \mu \mathrm{g} / \mathrm{mL}$, respectively; $P=$ 0.07). Plasma LBP concentrations were similar to the values reported by $\mathrm{Li}$ et al. (2012b) in control $(8.9 \mu \mathrm{g} /$ $\mathrm{mL})$ and in SARA-induced dairy cows $(12.1 \mu \mathrm{g} / \mathrm{mL})$. The increase in plasma concentrations of LBP suggests 
Table 8. Effect of feeding phases on DMI (kg/d) and milk production $(\mathrm{kg} / \mathrm{d})$ and composition (\%)

\begin{tabular}{|c|c|c|c|c|c|c|c|c|c|}
\hline Item & \multicolumn{2}{|c|}{ Adaptation (A) } & \multicolumn{2}{|l|}{ SARA (S) } & \multicolumn{2}{|l|}{ Rest (R) } & \multicolumn{3}{|c|}{ Probability ( $P$-value) } \\
\hline DMI & 25.3 & 0.16 & 23.0 & 0.60 & 24.1 & 0.39 & 0.0005 & 0.0006 & 0.12 \\
\hline $3.5 \% \mathrm{FCM}^{1}$ & 38.9 & 0.45 & 36.1 & 0.45 & 35.6 & 0.45 & 0.0001 & 0.0001 & 0.57 \\
\hline Feed efficiency ${ }^{2}$ & 1.64 & 0.02 & 1.74 & 0.02 & 1.63 & 0.02 & 0.003 & 0.009 & 0.003 \\
\hline \multicolumn{10}{|l|}{ Milk composition } \\
\hline Protein yield $(\mathrm{kg} / \mathrm{d})$ & 1.36 & 0.02 & 1.29 & 0.02 & 1.29 & 0.02 & 0.004 & 0.005 & 0.96 \\
\hline Urea-N (mg/100 mL) & 11.0 & 0.32 & 9.68 & 0.32 & 10.1 & 0.32 & 0.03 & 0.02 & 0.57 \\
\hline Lactose $(\%)$ & 4.58 & 0.01 & 4.59 & 0.01 & 4.54 & 0.02 & 0.01 & 0.59 & 0.01 \\
\hline Lactose yield (kg/d) & 1.90 & 0.02 & 1.82 & 0.02 & 1.77 & 0.02 & 0.001 & 0.02 & 0.24 \\
\hline $\mathrm{SCC}^{3}$ & $60.3[50.0-72.8]$ & - & $62.9[35.8-110.6]$ & - & $51.6[32.6-81.5]$ & - & 0.67 & 0.97 & 0.63 \\
\hline
\end{tabular}

${ }^{1} 3.5 \% \mathrm{FCM}=0.35(\mathrm{~kg}$ of milk production $/ \mathrm{d})+15.0(\mathrm{~kg}$ of fat $/ \mathrm{d})$.

${ }^{2}$ Feed efficiency $=$ milk production $(\mathrm{kg} / \mathrm{d}) / \mathrm{DMI}(\mathrm{kg} / \mathrm{d})$.

${ }^{3}$ Number of cells $\times 10^{3}$. Confidence intervals (in brackets) are presented instead of SEM, as data needed to be log-transformed because data distribution did not follow a normal curve.

that LPS translocated from rumen to blood and caused an acute phase response. However, plasma LPS concentration was below the detection limit in the present study as well as in the studies by Li et al. (2012a,b). Li et al. (2012b) explained this by the rapid detoxification of LPS in the liver before entering the peripheral blood circulation. Hence, LPS in peripheral blood will only increase if the capacity of the liver to break it down has been exceeded. Even though LPS do not make it past the liver, they may be detrimental to the animal; detoxification of LPS constitutes an energy cost at the liver level (Plaizier et al., 2012). Also, LPS in digesta may reduce the barrier function of the digestive-tract epithelium (Plaizier et al., 2012).

Cows receiving EFSC, during adaptation, tended to have lower plasma LBP $(4.57 \mu \mathrm{g} / \mathrm{mL})$ compared with those receiving EF $(11.8 \mu \mathrm{g} / \mathrm{mL} ; P=0.07$; Table 7$)$. Emmanuel et al. (2007) reported increased plasma concentration of SAA and LBP when EFSC was supplemented to feedlot steers receiving a high-grain diet ( $87 \%$ barley on DM basis). They attributed it to the release of endotoxins from a greater total number of coliform bacteria in treated animals than in control ones. In the present study, rumen LPS as well as plasma LBP and SAA concentrations decreased with EFSC, both during adaptation and SARA, which is worth further investigation, and which is consistent with the $\mathrm{pH}$ regulation by EFSC. Oppositely, greater concentrations of acute phase proteins were recorded with $\mathrm{EF}$ alone and associated with lower $\mathrm{pH}$ values than that with EFSC during adaptation.

Possibly, a decrease in rumen LPS may reduce its translocation to blood and thereby mitigate the acute phase response resulting from the SARA challenge.
Recently, Silberberg et al. (2013) reported decreased plasma SAA in SC-supplemented sheep during successive SARA challenges compared with the controls. These inflammatory data also coincided with increased ruminal $\mathrm{pH}$ in SC-supplemented sheep.

\section{DMI and Milk Yield and Composition}

Dry matter intake decreased significantly during SARA $(23.0 \mathrm{~kg} / \mathrm{d})$ compared with adaptation (25.3 $\mathrm{kg} / \mathrm{d} ; P<0.001)$ and did not recover completely during rest $(24.1 \mathrm{~kg} / \mathrm{d})$ as it was not different from DMI during SARA $(P=0.12$; Table 8$)$. It is common to observe depression in DMI with grain-induced SARA. The decrease in DMI observed in the present study is similar to that observed in a recent study $(-2.4 \mathrm{~kg} / \mathrm{d}$; Chiquette et al., 2012) with mid-lactation cows submitted to a SARA challenge. It was first attributed to decreased $\mathrm{pH}$ and change in rumen osmolarity (Allen, 2000). A recent study by Khafipour et al. (2009b) showed, however, that alfalfa pellets-induced SARA with similar changes in rumen $\mathrm{pH}$ and osmolarity did not depress DMI. They attributed it to the absence of an inflammatory response with alfalfa pellets-induced SARA as opposed to grain-induced SARA. Another explanation for the depression of DMI during SARA resides in the concurrent increase in propionate concentration in the rumen. Oba and Allen (2003) reported that propionate infused intraruminally decreased DMI in a dose-dependent manner. Direct-fed microbials had no effect on DMI ( $P=0.68$; data not shown).

Similarly, milk production, expressed as kilograms per day or FCM, decreased during SARA compared with adaptation $(P<0.01$; Figure 3 ; Table 8$)$. Average 


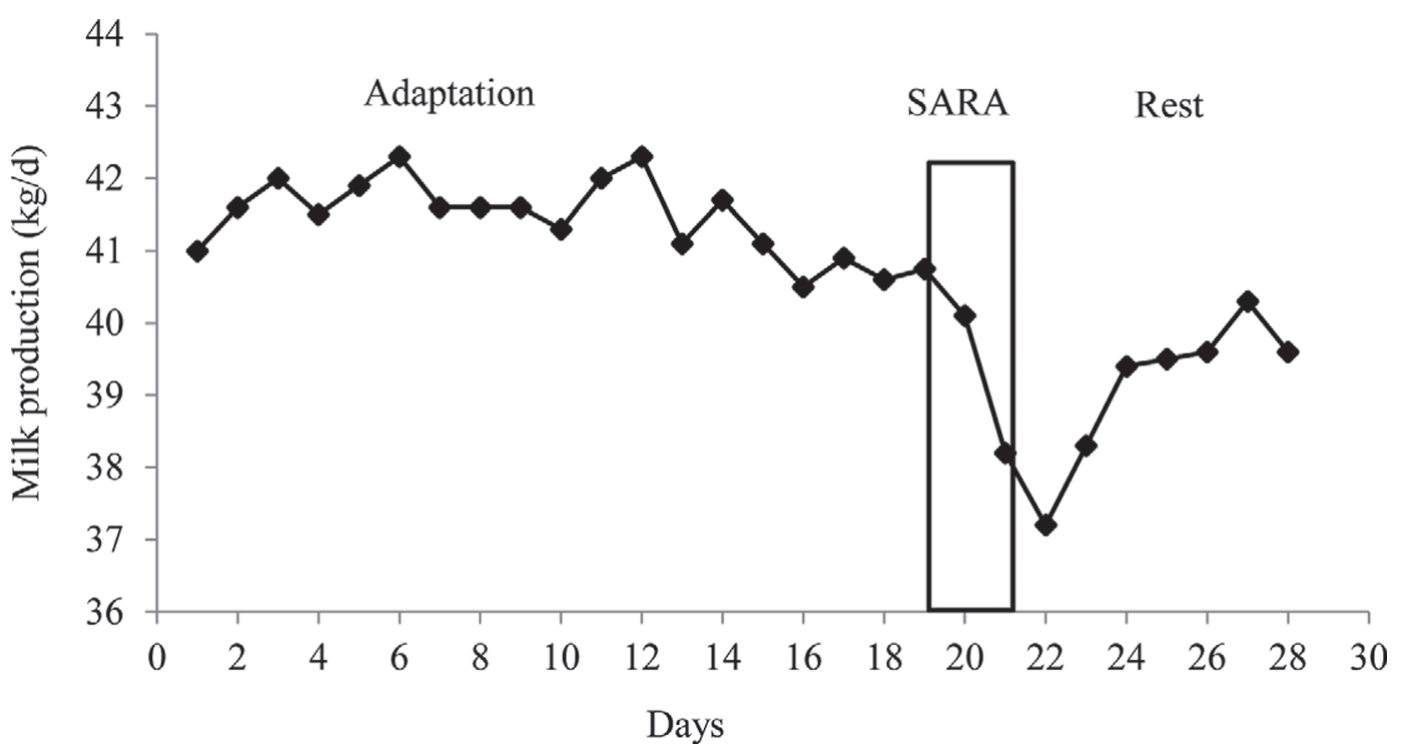

Figure 3. Effect of feeding phases on daily milk production $(\mathrm{kg} / \mathrm{d})$. The rectangle indicates the 3-d SARA challenge.

milk production during rest remained similar to that during SARA $(P=0.56)$. However, daily records of milk production showed a rapid recovery after a few days during the rest period (Figure 3). Feed efficiency increased during SARA $(P<0.01)$ and returned to adaptation value during rest $(P<0.01)$.

Milk-yield depression was observed in many studies with grain-induced SARA. Khafipour et al. (2009a) reported a $3.3-\mathrm{kg} / \mathrm{d}$ decrease in milk yield from control to SARA diet. In the present study, milk yield was decreased by $1.8 \mathrm{~kg} / \mathrm{d}$ during SARA as opposed to the adaptation period. In a previous study (Chiquette et al., 2012) where a more severe SARA challenge was induced, milk yield decrease was $2.2 \mathrm{~kg} / \mathrm{d}$, which is similar to the $2.7 \mathrm{~kg} / \mathrm{d}$ reported from a large field study by Stone (1999). Krause et al. (2009) also observed reduced milk yield during one bout of SARA $(-6.7$ $\mathrm{kg} / \mathrm{d}$ ). As in the present study, milk yield did not return to pre-SARA values during the recovery period.

The drop in milk yield from d 1 to 3 of SARA was lower with EFSC $(-0.8 \mathrm{~kg} / \mathrm{d}), \operatorname{EF}(-0.9 \mathrm{~kg} / \mathrm{d})$, or EFLL $(-0.9 \mathrm{~kg} / \mathrm{d})$ compared with CON $(-7.5 \mathrm{~kg} / \mathrm{d} ; P$ $=0.03$; Figure 4$)$. Overall, however, DFM had no effect $(P=0.68)$ on average milk production during any of the experimental phases. Nocek et al. (2003) observed increased milk yield $(+1.6 \mathrm{~kg} / \mathrm{d}$ on average) when feeding EFSC during the first $10 \mathrm{wk}$ of lactation.

Milk fat percentage tended $(P=0.07)$ to decrease during SARA $(3.75 \%)$ compared with adaptation $(3.93 \%)$ and remained low during rest (3.74\%; Table 8). Similarly, milk urea-N decreased during SARA (9.68 $\mathrm{mg} / \mathrm{dL})$ compared with adaptation $(11.0 \mathrm{mg} / \mathrm{dL} ; P=$ $0.02)$ and remained low during rest $(10.1 \mathrm{mg} / \mathrm{dL})$. Milk protein percentage decreased during SARA (3.25\%) compared with rest $(3.32 \% ; P=0.01)$, whereas lactose percentage increased during SARA $(4.59 \%)$ versus rest $(4.54 \% ; P=0.01)$. Although the concentration of milk constituents was not affected similarly between feeding phases, when expressed as milk-constituents yield $(\mathrm{kg} / \mathrm{d})$, all (fat, protein, and lactose) decreased during SARA compared with adaptation and did not recover during the rest phase compared with SARA. Depres-

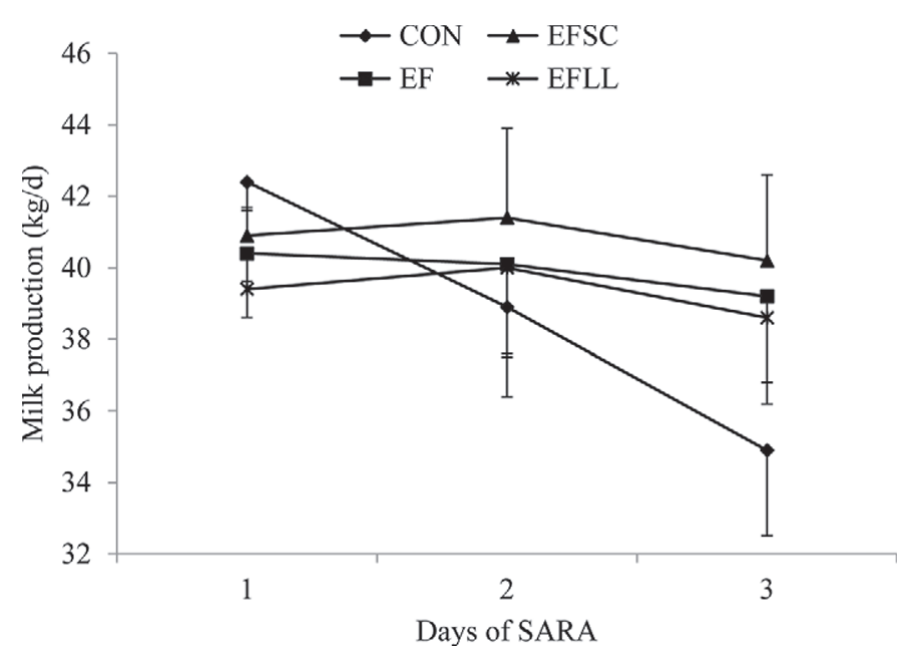

Figure 4. Effect of direct-fed microbials on daily milk production $(\mathrm{kg} / \mathrm{d})$ during SARA. Treatments are represented by the following: $\mathrm{CON}=$ control $; \mathrm{EF}=$ Enterococcus faecium [mixture of 3 strains: $E$. faecium $1\left(1.2 \times 10^{9} \mathrm{cfu} / \mathrm{g}\right)$, E. faecium $2\left(1.2 \times 10^{9} \mathrm{cfu} / \mathrm{g}\right)$, and $E$. faecium $\left.3\left(1.3 \times 10^{7} \mathrm{cfu} / \mathrm{g}\right)\right] ; \mathrm{EFSC}=\mathrm{EF}+$ Saccharomyces cerevisiae $\left(1 \times 10^{9} \mathrm{cfu} / \mathrm{g}\right) ; \mathrm{EFLL}=\mathrm{EF}+$ Lactococcus lactis DSM $11037(2.8 \times$ $\left.10^{9} \mathrm{cfu} / \mathrm{g}\right)$. Error bars indicate SEM. 
sion in milk fat and urea-N concentrations is commonly observed during SARA (Plaizier et al., 2008). Lowered milk fat content is often used as an indicator of SARA in dairy herds (Enemark, 2008). A field study on a large dairy farm found that SARA reduced the production of milk, milk fat, and milk protein concentrations by 2.7 $\mathrm{kg} / \mathrm{d}, 0.3 \%$, and $0.12 \%$, respectively (Stone 1999) compared with $1.8 \mathrm{~kg} / \mathrm{d}, 0.18 \%$, and $0.04 \%$, respectively in the present study. The difference between the 2 studies is probably due to the duration of SARA bouts, which was shorter in the present study (3 d) than in Stone (1999), where a herd of 500 Holstein dairy cows experienced SARA for 2 mo before diet adjustment.

The lower concentration of milk urea-N during SARA compared with adaptation could be explained by utilization of $\mathrm{NH}_{3}-\mathrm{N}$ together with high $\mathrm{CHO}$ content for microbial protein synthesis at the rumen level, at the expense of urea- $\mathrm{N}$ formation.

Somatic cell counts were not affected by feeding phase. Milk composition was not affected by DFM.

\section{CONCLUSIONS}

All DFM prevented a decrease in milk production from $d 1$ to 3 of SARA compared with CON. Generally, EFSC and EFLL gave a better response than EF alone or $\mathrm{CON}$ in term of $\mathrm{pH}$ regulation and maintenance of protozoa populations during SARA. The treatment EFSC tended to be superior to all other treatments to maintain a greater vitamin $\mathrm{B}_{12}$ concentration in the rumen when cows were subjected to SARA.

\section{ACKNOWLEDGMENTS}

Authors acknowledge the following persons from the Dairy and Swine Research and Development Centre (Sherbrooke, Canada): J. Brochu and M. Alain-Fleury for technical work, M.-E. Bouchard for her help at the barn, and S. Méthot for statistical support. This project was financially supported by Chr. Hansen Inc. (Hørsholm, Denmark).

\section{REFERENCES}

Allen, M. S. 2000. Effects of diet on short-term regulation of feed intake by lactating dairy cattle. J. Dairy Sci. 83:1598-1624.

AlZahal, O., B. Rustomo, N. E. Odongo, T. F. Duffield, and B. W. McBride. 2007. Technical note: A system for continuous recording of ruminal $\mathrm{pH}$ in cattle. J. Anim. Sci. 85:213-217.

Ametaj, B. N., B. J. Bradford, G. Bobe, R. A. Nafikov, Y. Lu, J. W. Young, and D. C. Beitz. 2005. Strong relationships between mediators of the acute phase response and fatty liver in dairy cows. Can. J. Anim. Sci. 85:165-175.

Anderson, P. J., B. Entsch, and D. B. McKay. 2001. A gene, $\operatorname{cobA}$ + hemD, from Selenomonas ruminantium encodes a bifunctional enzyme involved in the synthesis of vitamin $B_{12}$. Gene 281:63-70.
Canadian Council on Animal Care in Science. 2009. The Care and Use of Farm Animals in Research, Teaching and Testing. Can. Counc. Anim. Care, Ottawa, ON, Canada.

Chiquette, J. 2009. Evaluation of the protective effect of DFM fed to dairy cows during a subacute ruminal acidosis challenge. Anim. Feed Sci. Technol. 153:278-291.

Chiquette, J., M. J. Allison, and M. Rasmussen. 2012. Use of Prevotella bryantii $25 \mathrm{~A}$ and a commercial DFM during subacute acidosis challenge in midlactation dairy cows. J. Dairy Sci. 95:5985-5995.

Denman, S. E., and C. S. McSweeney. 2006. Development of a realtime PCR assay for monitoring anaerobic fungal and cellulolytic bacterial populations within the rumen. FEMS Microbiol. Ecol. 58:572-582.

Donaldson, M. S. 2000. Metabolic vitamin B12 status on a mostly raw vegan diet with follow-up using tablets, nutritional yeast, or probiotic supplements. Ann. Nutr. Metab. 44:229-234.

Dryden, L. P., A. M. Hartman, M. P. Bryant, I. M. Robinson, and L. A. Moore. 1962. Production of vitamin B12 and vitamin B12 analogues by pure cultures of ruminal bacteria. Nature 195:201-202.

Dufrêne, M., and P. Legendre. 1997. Species assemblages and indicator species: The need for a flexible asymmetrical approach. Ecol. Monogr. 67:345-366.

Ellis, J. E., A. G. Williams, and D. Lloyd. 1989. Oxygen consumption by ruminal microorganisms: Protozoal and bacterial contributions. Appl. Environ. Microbiol. 55:2583-2587.

Emmanuel, D. G., A. Jafari, K. A. Beauchemin, J. A. Leedle, and B. N. Ametaj. 2007. Feeding live cultures of Enterococcus faecium and Saccharomyces cerevisiae induces an inflammatory response in feedlot steers. J. Anim. Sci. 85:233-239.

Enemark, J. M. D. 2008. The monitoring, prevention and treatment of sub-acute ruminal acidosis (SARA): A review. Vet. J. 176:32-43.

Girard, C. L., and A. Desrochers. 2010. Net flux of nutrients across splanchnic tissues of lactating dairy cows as influenced by dietary supplements of biotin and vitamin $\mathrm{B}_{12}$. J. Dairy Sci. 93:16441654 .

Gozho, G. N., J. C. Plaizier, D. O. Krause, A. D. Kennedy, and K. M. Wittenberg. 2005. Subacute ruminal acidosis induces ruminal lipopolysaccharides endotoxin release and triggers an inflammatory response. J. Dairy Sci. 88:1399-1403.

Hindrichsen, I. K., E. U. Augustsson, B. Lund, M. M. Jensen, M. Raun, J. Jatkauskas, V. Vrotniakiene, and C. Ohlsson. 2012. Characterisation of different lactic acid bacteria in terms of their oxygen consuming capacity, aerobic stability and pathogen inhibition. Pages 105-106 in Proc. XVI Int. Silage Conf., Hameenlinna, Finland. MTT Agrifood Research Finland, University of Helsinki, Finland.

Keunen, J. E., J. C. Plaizier, L. Kyriazakis, T. F. Duffield, T. M. Widowski, M. I. Lindinger, and B. W. Mc Bride. 2002. Effects of a subacute ruminal acidosis model on the diet selection of dairy cows. J. Dairy Sci. 85:3304-3313.

Khafipour, E., D. O. Krause, and J. C. Plaizier. 2009a. A grain-based subacute ruminal acidosis challenge causes translocation of lipopolysaccharide and triggers inflammation. J. Dairy Sci. 92:10601070.

Khafipour, E., D. O. Krause, and J. C. Plaizier. 2009b. Alfalfa pelletinduced subacute ruminal acidosis in dairy cows increases bacterial endotoxin in the rumen without causing inflammation. J. Dairy Sci. 92:1712-1724.

Khafipour, E., L. Shucong, J. C. Plaizier, and D. O. Krause. 2009c. Rumen microbiome composition using two nutritional models of subacute ruminal acidosis. Appl. Environ. Microbiol. 75:71157124 .

Krause, K. M., D. V. Dhuyvetter, and G. R. Oetzel. 2009. Effect of a low-moisture buffer block on ruminal $\mathrm{pH}$ in lactating dairy cattle induced with subacute ruminal acidosis. J. Dairy Sci. 92:352-364.

Krause, K. M., and G. R. Oetzel. 2005. Inducing subacute ruminal acidosis in lactating dairy cows. J. Dairy Sci. 88:3633-3639.

Krizova, L., M. Richter, J. Trinacty, J. Riha, and D. Kumprechtova. 2011. The effect of feeding live yeast cultures on ruminal $\mathrm{pH}$ and Eh potential in dry cows as continuously measured by a new wireless device. Czech J. Anim. Sci. 56:37-45. 
Li, S., G. N. Gozho, N. Gakhar, E. Khafipour, D. O. Krause, and J. C. Plaizier. 2012a. Evaluation of diagnostic measures for subacute ruminal acidosis in dairy cows. Can. J. Anim. Sci. 92:353-364.

Li, S., E. Khafipour, D. O. Krause, A. Kroeker, J. C. RodriguezLecompte, G. N. Gozho, and J. C. Plaizier. 2012b. Effects of subacute ruminal acidosis challenges on fermentation and endotoxins in the rumen and hindgut of dairy cows. J. Dairy Sci. 95:294-303.

Maeda, H., C. Fujimoto, Y. Haruki, T. Maeda, S. Kokeguchi, M. Petelin, H. Arai, I. Tanimoto, F. Nishimura, and S. Takashiba. 2003. Quantitative real-time PCR using TaqMan and SYBR Green for Actinobacillus actinomycetemcomitans, Porphyromonas gingivalis, Prevotella intermedia, tetQ gene and total bacteria. FEMS Immunol. Med. Microbiol. 39:81-86.

Marden, J. P., and C. Bayourthe. 2005. Live yeasts-ruminal $\mathrm{O}_{2}$ scavenger and pH stabilizer. Feed Mix 13:2-4.

Marden, J. P., C. Bayourthe, F. Enjalbert, and R. Moncoulon. 2005. A new device for measuring kinetics of ruminal $\mathrm{pH}$ and redox potential in dairy cattle. J. Dairy Sci. 88:277-281.

Martens, J.-H., H. Barg, W. J. Warren, and D. Jahn. 2002. Microbial production of vitamin B12. Appl. Microbiol. Biotechnol. 58:275285 .

Mathieu, F., J. P. Jouany, J. Sénaud, J. Bohatier, G. Bertin, and M. Mercier. 1996. The effect of Saccharomyces cerevisiae and Aspergillus oryzae on fermentation in the rumen of faunated and defaunated sheep; protozoal and DFM interactions. Reprod. Nutr. Dev. $36: 271-287$.

McCune, B., J. B. Grace, and D. L. Urban. 2002. Analysis of Ecological Communities. MjM Software Design, Gleneden Beach, Oregon.

Mertens, D. R. 2002. Gravimetric determination of amylase-treated neutral detergent fiber in feeds using refluxing in beakers or crucibles: Collaborative study. J. AOAC Int. 85:1217-1240.

Nagaraja, T. G., and E. C. Titgemeyer. 2007. Ruminal acidosis in beef cattle: The current microbiological and nutritional outlook. J. Dairy Sci. 90(Suppl. 1):E17-E38.

NRC. 2001. Nutrient Requirements of Dairy Cattle. 7th rev. ed. Natl. Acad. Sci., Washington, DC.

Newbold, C. J., R. J. Wallace, and F. M. McIntosh. 1996. Mode of action of the yeast Saccharomyces cerevisiae as a feed additive for ruminants. Br. J. Nutr. 76:249-261.

Nisbet, D. J., and S. A. Martin. 1991. The effect of Saccharomyces cerevisiae cultures on lactate utilization by the ruminal bacterium Selenomonas ruminantium. J. Anim. Sci. 69:4628-4633.

Nocek, J. E., W. P. Kautz, J. A. Z. Leedle, and J. G. Allman. 2002. Ruminal supplementation of direct-fed microbials on diurnal $\mathrm{pH}$ variation and in situ digestion in dairy cattle. J. Dairy Sci. 85:429-433.

Nocek, J. E., W. P. Kautz, J. A. Z. Leedle, and E. Block. 2003. DFM supplementation on the performance of dairy cattle during the transition period. J. Dairy Sci. 86:331-335.

Oba, M., and M. S. Allen. 2003. Intraruminal infusion of propionate alters feeding behavior and decreases energy intake of lactating dairy cows. J. Nutr. 133:1094-1099.
Owens, F. N., D. S. Secrist, W. J. Hill, and D. R. Gill. 1998. Acidosis in cattle-A review. J. Anim. Sci. 76:275-286.

Petri, R. M., T. Schwaiger, G. B. Penner, K. A. Beauchemin, R. J. Forster, J. J. McKinnon, and T. A. McAllister. 2013. Characterization of the core rumen microbiome in cattle during transition from forage to concentrate as well as during and after an acidotic challenge. PLoS ONE 8:e83424.

Piao, Y., M. Yamashita, N. Kawaraichi, R. Asegawa, H. Ono, and Y. Murooka. 2004. Production of vitamin $\mathrm{B}_{12}$ in genetically engineered Propionibacterium freudenreichii. J. Biosci. Bioeng. 98:167-173.

Plaizier, J. C.. D. O. Krause, G. N. Gozho, and B. W. McBride. 2008. Subacute ruminal acidosis in dairy cows: The physiological causes, incidence and consequences. Vet. J. 176:21-31.

Plaizier, J. C., S. Li, E. Khafipour, G. N. Gozho, and D. O. Krause. 2012. Sub-acute rumen acidosis (SARA), endotoxins and health consequences. Anim. Feed Sci. Technol. 172:9-21.

Roy, C. S., G. Talbot, E. Topp, C. Beaulieu, M. F. Palin, and D. I Massé. 2009. Bacterial community dynamics in an anaerobic plugflow type bioreactor treating swine manure. Water Res. 43:21-32.

SAS Institute Inc. 2002. Statistical Analysis System. Release 9.1. SAS Inst. Inc., Cary, NC.

Schwab, E. C., C. G. Schwab, R. D. Shaver, C. L. Girard, D. E. Putnam, and N. L. Whitehouse. 2006. Dietary forage and nonfiber carbohydrate contents influence B-vitamin intake, duodenal flow, and apparent ruminal synthesis in lactating dairy cows. J. Dairy Sci. 89:174-187.

Scott, H. W., and B. A. Dehority. 1965. Vitamin requirements of several cellulolytic rumen bacteria. J. Bacteriol. 89:1169-1175.

Silberberg, M., F. Chaucheyras-Durand, L. Commun, M. M. Mialon, V. Monteils, P. Mosoni, D. P. Morgavi, and C. Martin. 2013. Repeated acidosis challenges and live yeast supplementation shape rumen microbiota and fermentations and modulate inflammatory status in sheep. Animal 7:1910-1920.

Slyter, L. L. 1976. Influence of acidosis on rumen function. J. Anim. Sci. 43:910-929.

Stone, W. C. 1999. The effect of subclinical ruminal acidosis on milk components. Pages 40-46 in Proc. Cornell Nutr. Conf. Feed Manuf., Rochester, NY. Cornell University, Ithaca, NY.

Suzuki, M., M. S. Rappe, and S. J. Giovannoni. 1998. Kinetic bias in estimates of coastal picoplankton community structure obtained by measurements of small-subunit rRNA gene PCR amplicon length heterogeneity. Appl. Environ. Microbiol. 64:4522-4529.

Sylvester, J. T., S. K. R. Karnati, Z. T. Yu, M. Morrison, and J. L. Firkins. 2004. Development of an assay to quantify rumen ciliate protozoal biomass in cows using real-time PCR. J. Nutr. 134:3378-3384.

Tajima, K., S. Arai, K. Ogata, T. Nagamine, H. Matsui, M. Nakamura, R. I. Aminov, and Y. Benno. 2000. Rumen bacterial community transition during adaptation to high-grain diet. Anaerobe $6: 273-284$. 